\title{
Real Time PCR Based Expression of Metallothionein and Evaluation of Zn Bioavailability in Chickens Fed Zinc Oxide and Zinc Methionine
}

\author{
A. $\operatorname{Varun}^{1 *}$, N. Karthikeyan ${ }^{1}$, P. Muthusamy ${ }^{2}$, A. Raja ${ }^{3}$ and S. Wilfred Ruban ${ }^{4}$ \\ ${ }^{1}$ Department of Poultry Science, Madras Veterinary College, Chennai, Tamil Nadu, India \\ ${ }^{2}$ Post Graduate Research Institute in Animal Sciences, TANUVAS, Kattupakkam, \\ Tamil Nadu, India \\ ${ }^{3}$ Department of Microbiology, VCRI, Namakkal, Tamil Nadu, India \\ ${ }^{4}$ Department of Livestock Product Technology, Veterinary College, Bengaluru, Karnataka, India \\ *Corresponding author
}

\section{A B S T R A C T}

Keywords

Zinc,

Bioavailability, Metallotheionein, RT-PCR, ZnMethionine.

Article Info

Accepted:

14 June 2017

Available Online:

10 July 2017
An experiment was conducted to investigate the bioavailability of different forms and concentration of Zinc $(\mathrm{Zn})$ fed to chickens and Metallotheionein (MT) expression by Real time Polymerase Chain Reaction (RT-PCR). In the present study broiler birds were fed with corn-soya based basal diet (BD) as control $\left(\mathrm{T}_{1}\right)$, $\mathrm{BD}$ with $\mathrm{ZnO} 80 \mathrm{ppm}\left(\mathrm{T}_{2}\right)$ and $\mathrm{BD}$ with 40 and $80 \mathrm{ppm}$ of $\mathrm{Zn}$-methionine $\left(\mathrm{T}_{3}\right.$ and $\mathrm{T}_{4}$ ) respectively, for a period of 42 days. At day 42, six birds from each treatment were slaughtered, liver and duodenal scrapings were collected for MT expression, whereas tibia and serum were collected for $\mathrm{Zn}$ estimation. When compared with control, all the treatment groups had higher levels of $\mathrm{Zn}$ in tibia and serum and also up regulation of MT mRNA significantly. But, birds fed with Zn- methionine exhibited MT expression significantly greater than all other treatments and suggesting that $\mathrm{Zn}$-met form is more bioavailable than $\mathrm{ZnO}$. Subsequent commercial trails with reduced (50 \%) mineral inputs via $\mathrm{Zn}$-Methionine revealed equal performance characteristics as compared to inorganic $\mathrm{Zn}$ feeding at 100 per cent level.

\section{Introduction}

Zinc $(\mathrm{Zn})$ as a micro mineral is essential for growth, skeletal development, and immune competence in chickens (Hudson et al., 2004). Inorganic $\mathrm{Zn}$ salts, such as sulphate and oxide, are generally supplemented in diets to meet the $\mathrm{Zn}$ requirement of chickens (Cao et al., 2002). However, in the recent past Inorganic trace minerals (ITMs) have been replaced by organic trace minerals (OTMs) because of higher bioavailability and considerable reduction in cost of mineral supplementation. Several researchers have conducted different trails with both organic and inorganic $\mathrm{Zn}$ supplementation and they have observed increased availability in organic forms of minerals (Yan Waldroup, 2006 and Ao et al., 2011).

However, in some studies, no differences in bioavailability were observed between 
organic and inorganic forms of $\mathrm{Zn}$ products (Pimentel et al., 1991 and Haung et al., 2009). These discrepancies might be related to the degree of chelation or complexation of the $\mathrm{Zn}$ ion to organic ligands.

It has been documented that $\mathrm{Zn}$-methionine supplementation in broiler Chicken was more effective in promoting growth with less interaction with other minerals than $\mathrm{Zn}$ sulphate (Ao et al., 2011). However, the relative bioavailability of this $\mathrm{Zn}$-methionine has not been experimentally verified by using gene expression studies. Serum and bone $\mathrm{Zn}$ accumulation is generally used to measure the bioavailability of different $\mathrm{Zn}$ sources for chicks. Metallothionein (MT), a Zn-binding protein, plays a critical role in $\mathrm{Zn}$ transport and storage and hence MT expression is widely used as an indicator of the $\mathrm{Zn}$ status and also to evaluate the bioavailability. Liver and intestine MT mRNA level has been more sensitive than tibia $\mathrm{Zn}$ concentration in differentiating the differences in the bioavailability of various $\mathrm{Zn}$ sources for chickens. Therefore, the objective of this study was to investigate the bioavailability of $\mathrm{Zn}$ sources fed to chickens and Metallotheionein (MT) expression by Real time Polymerase Chain Reaction (RT-PCR).

\section{Materials and Methods}

The present study was performed in the Department of Poultry Science, Madras Veterinary College, TANUVAS (Chennai, India). Vencobb 400 chicks $(n=120)$ were randomly allotted to 3 replicate with 10 chicks each and these replicate were distributed randomly to 4 dietary treatments. A corn-soybean meal diet without $\mathrm{Zn}$ supplementation was used as a basal diet $\left(\mathrm{T}_{1^{-}}\right.$control). Basal diet with inorganic $\mathrm{Zn}(\mathrm{ZnO})$ at $80 \mathrm{ppm}\left(\mathrm{T}_{2}\right)$ and organic $\mathrm{Zn} \quad(\mathrm{Zn}$ methionine) at 40 and $80 \mathrm{ppm}\left(\mathrm{T}_{3}\right.$ and $\left.\mathrm{T}_{4}\right)$, respectively forms the treatment groups. The birds were raised in brooder cum grower cages under uniform management for a period of 42 days. At the end of $42^{\text {th }}$ day, two broiler chickens from each replicate will be slaughtered, liver and duodenal scrapings were collected to measure the MT mRNA expression by RT-PCR whereas, tibia and serum for estimation of $\mathrm{Zn}$ concentration.

Blood samples were collected from the brachial vein and processed for serum separation. Serum samples were stored at $20^{\circ} \mathrm{C}$ until further analysis. After slaughter the bone (left tibia) were collected and adhering muscles were removed manually. Then these bones were dipped in $10 \%$ sodium hydroxide $(\mathrm{NaOH})$ solution for 5 min to remove the adhering fine and soft tissue. These bones were dried in hot air oven overnight. Defattening of dried bones was done with diethyl ether and petroleum sprit. Dried bones were ashed at $650^{\circ} \mathrm{C}$ for $4 \mathrm{~h}$ in muffle furnace as per the method of AOAC (2000). The Zn content in the tibia and serum was estimated by using Atomic absorption spectrophotometer (Perkin Elmer Analyst 400).The primers used for RT-PCR to amplify MT gene along with endogenous control $\beta$ actin gene of Gallus gallus domesticus and the cyclic conditions are listed in tables 1 and 2 .

The RT- PCR was carried out using SYBR green based method for the zinc specific gene in eppendr off qPCR master cycler using SYBR Premix Ex Taq (Sigma, Invitrogen, USA). The real-time quantitative PCR data were analysed using the $2^{-\Delta \Delta^{c t}}$ method reported by Livak and Schmittgen (2001), and $\beta$-actin was chosen as a reference to normalise the expression level of MT mRNA.

\section{Results and Discussion}

\section{Tibia and serum $\mathbf{Z n}$}

The effect of inorganic and organic $\mathrm{Zn}$ supplementation along with control on the 
tibia and serum $\mathrm{Zn}$ concentration of broiler chickens are presented in table 3 . The mean tibia and serum $\mathrm{Zn}$ concentration was highly significant $(\mathrm{P}<0.01)$ in the treatment groups when compared to control groups. The mean tibia $\mathrm{Zn}$ concentration (ppm) was 106.94, 116.44 and 112.48 in the treatment groups $\left(\mathrm{T}_{2}, \mathrm{~T}_{3}\right.$ and $\left.\mathrm{T}_{4}\right)$ as compared to 59.45 in the control. Whereas, serum $\mathrm{Zn}$ concentration (ppm) was 2.07, 2.29 and 2.25 in the treatment groups $\left(\mathrm{T}_{2}, \mathrm{~T}_{3}\right.$ and $\left.\mathrm{T}_{4}\right)$ as compared to 0.96 in the control. Similar results have been reported by Sunder et al., (2008) who have noticed a linear increase in $\mathrm{Zn}$ deposition in bone with respect to $\mathrm{Zn}$ supplementation in the diets of broilers.

The findings of the present study are in agreement with Tronina et al., (2007) who evaluated the $\mathrm{Zn}$ content in tibia bone for broiler chickens supplemented with inorganic $(\mathrm{ZnO})$ and organic (Zn-glycine) zinc and observed increased concentration of zinc in the Zn-glycine supplemented groups. Similarly, Bartlett and Smith (2003) observed that broilers supplemented with $\mathrm{Zn}$ showed a positive correlation of tibial $\mathrm{Zn}$ concentration with increasing concentration of $\mathrm{Zn}$ in the feed.Thus, it could be inferred from the results that birds supplemented with the organic $\mathrm{Zn}$ showed higher tibia and serum $\mathrm{Zn}$ concentration when compared to the inorganic $\mathrm{Zn}$ supplemented group and control. The mechanism for this might be explained by the antagonism occurring between $\mathrm{Zn}$ and other minerals (such as $\mathrm{Cu}$ ) when included in inorganic forms as compared to inclusion of zinc in organic forms in diet.

\section{MT mRNA expression}

The results of the present study revealed a highly significant $(\mathrm{P}<0.01)$ up regulated expression of MT gene in organic and inorganic Zn treatments when compared with control. But, the expression in inorganic $\mathrm{Zn}$ was low when compared with organic source of $\mathrm{Zn}$. Liver and intestinal MT mRNA expression for different treatment groups are shown in figure 1 . The mean relative expression of MT mRNA in liver was 3.4, 6.1 and 3.3 in the treatment groups $\left(\mathrm{T}_{2}, \mathrm{~T}_{3}\right.$ and $\mathrm{T}_{4}$ ) as compared to 1.0 in the control. Whereas, the mean relative expression of MT mRNA in intestine was $15.4,49.3$ and 44.4 in the treatment groups $\left(\mathrm{T}_{2}, \mathrm{~T}_{3}\right.$ and $\left.\mathrm{T}_{4}\right)$ as compared to 1.0 in the control.

Table.1 List of oligonucleotide primers for Real time PCR

\begin{tabular}{|l|l|l|}
\hline Primers & Sequence (5' to 3') & Product size \\
\hline MT-FP & AAG GGC TGT GTC TGC AAG GA & $163 \mathrm{bp}$ \\
MT-RP & CTT CAT CGG TAT GGA AGG TAC AAA & \\
\hline $\begin{array}{l}\beta \text {-actin-FP } \\
\beta \text {-actin -RP }\end{array}$ & GAG AAA TTG TGC GTG ACA TCA & $152 \mathrm{bp}$ \\
\hline
\end{tabular}

Table.2 The cyclic conditions used for RT-PCR

\begin{tabular}{|c|c|c|c|}
\hline Step & Temperature & Time & \\
\hline Initial denaturation & $95^{\circ} \mathrm{C}$ & 2 min. & \\
\hline Denaturation & $95^{\circ} \mathrm{C}$ & $10 \mathrm{sec}$ & \multirow{3}{*}{$\begin{array}{l}\text { Cycling stage } \\
40 \text { cycles }\end{array}$} \\
\hline Annealing & $62^{\circ} \mathrm{C}$ & $20 \mathrm{sec}$ & \\
\hline Extension & $72^{\circ} \mathrm{C}$ & $45 \mathrm{sec}$ & \\
\hline Melt curve & \multicolumn{3}{|c|}{ Default settings } \\
\hline
\end{tabular}


Table.3 Mean $( \pm \mathrm{SE})$ tibia and serum Zn concentration $(\mathrm{ppm})$ in broiler chickens Fed with inorganic and organic zinc

\begin{tabular}{|c|c|c|}
\hline Treatments(in ppm) & Tibia Zn $\mathbf{~} \mathbf{p p m})$ & Serum Zn $\mathbf{~ p p m )}$ \\
\hline T1Control & $59.45^{\mathrm{c}} \pm 1.82$ & $0.96^{\mathrm{b}} \pm 0.08$ \\
\hline T2ZnO $-\mathbf{8 0}$ & $106.94^{\mathrm{a} b} \pm 0.47$ & $2.07^{\mathrm{a}} \pm 0.02$ \\
\hline T3Zn-met $-\mathbf{4 0}$ & $116.44^{\mathrm{a}} \pm 2.10$ & $2.29^{\mathrm{a}} \pm 0.05$ \\
\hline T4Zn-met $\mathbf{- 8 0}$ & $112.48^{\mathrm{ab}} \pm 1.38$ & $2.25^{\mathrm{a}} \pm 0.04$ \\
\hline F value & $\mathbf{5 5 . 0 0 7}$ & $\mathbf{3 3 . 0 4 6}$ \\
\hline Significance & \multicolumn{2}{|c|}{$* *$ Highly significant $(\mathrm{P}<0.01)$} \\
\hline
\end{tabular}

Means bearing different superscripts within the same column differ significantly $(\mathrm{P}<0.05)$

Fig.1 Mean $( \pm$ SE) relative expression of MT mRNA in broiler chickens Fed with inorganic and organic zinc

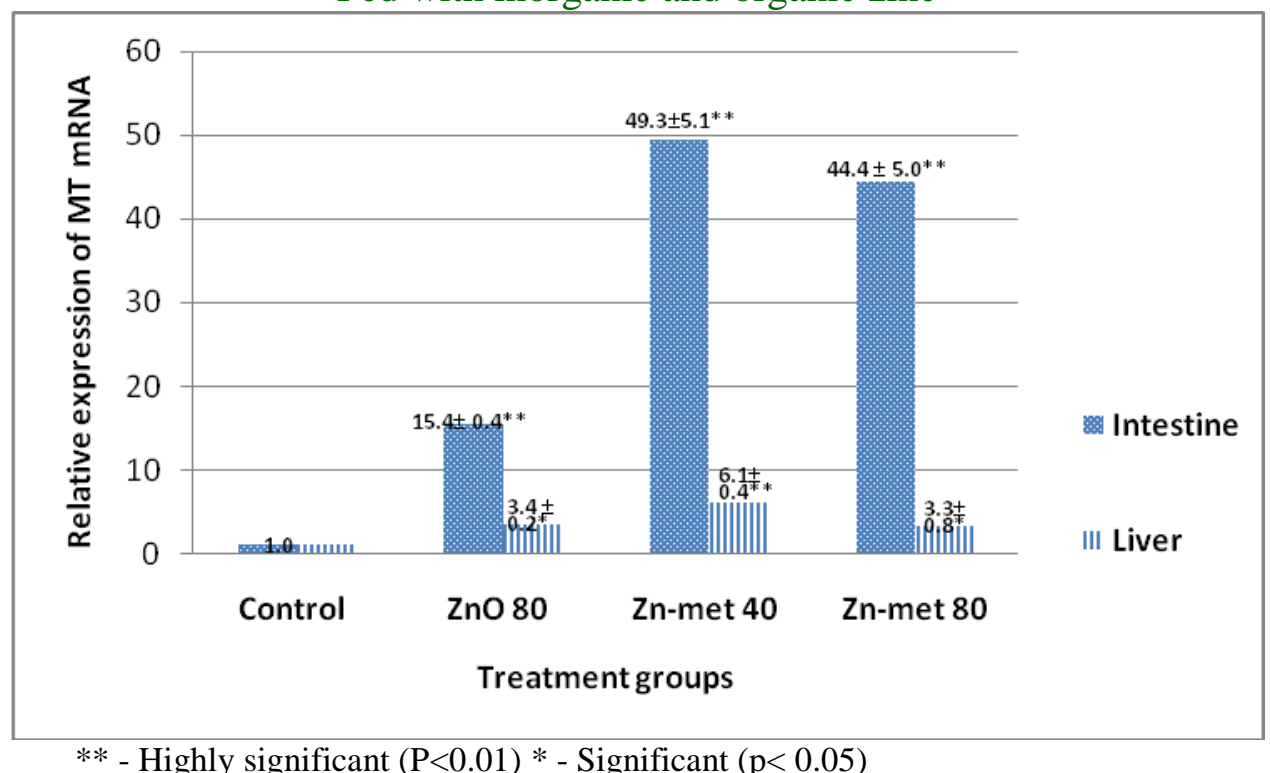

** - Highly significant $(\mathrm{P}<0.01) *$ - Significant $(\mathrm{p}<0.05)$

The findings of the present study are in agreement with Huang et al., (2007) who reported that $\mathrm{Zn}$ supplementation linearly increased MT expression in pancreas. Similarly, Cheng and Guo (2004) compared the inorganic $\mathrm{Zn}$ and $\mathrm{Zn}$ amino acid ( $\mathrm{ZnAA})$ chelates with MT expression and suggested that ZnAA complex enhanced MT synthesis in liver. Cao et al., (2002) and Liu et al., (2013) reported that supplementation of organic Zn showed an increased MT mRNA expression when compared with $\mathrm{ZnSO} 4$ and control. Brooks et al., (2013) reported that relative bioavailability of $\mathrm{Zn}$ from organic $\mathrm{Zn}$ was much higher than $\mathrm{Zn}$ sulphate.
Based on the results of the present study it was evident that when birds are fed with corn soya based diet, containing the dietary antagonist phytic acid and inorganic, the $\mathrm{Zn}$ usually reacts with phytic acid and unutilized as Zn-phytate complex. Whereas, the increased bioavailability of chelated trace minerals is likely due to its reduced antagonistic reactions with other dietary constituents in the GI tract of the bird. Another possible reason is its chelation strength. The organic trace elements with the moderate chelation strength displayed the highest relative bioavailability, followed by elements with the strong chelation strength, 
and those with the weak chelation strengths were as available as their inorganic forms. Hence, Zn-met with moderate chelation strength have higher bioavailability when compared with inorganic $\mathrm{Zn}$.

From our study it was concluded that organic source of $\mathrm{Zn}$ (Zn-met) have relatively higher bioavailability and supports the performance in the broilers. Furthermore, Zinc methionine was more effective than inorganic $\mathrm{Zn}$ in enhancing the MT mRNA expression in broilers.

\section{References}

Ao, T., J. L. Pierce, A. J. Pescatore, A. H. Cantor, K. A. Dawson, M. J. Ford and M. Paul, 2011. Effects of feeding different concentration and forms of zinc on the performance and tissue mineral status of broiler chicks. Br Poult Sci. 52(4):466-71.

AOAC. 2000. Official Methods of Analysis 15th ed. Association of Official Analytical Chemists. Arlington, VA.

Bartlett, J. R., and M. O. Smith. 2003. Effects of different levels of zinc on the performance and immune competence of broilers under heat stress. Poult. Sci. 82:1580-1588

Cao, J., P.R. Henry, R. Guo, R. A. Holwerda, J.P. Toth, R.C. LittelL, R.D. Miles and C.B. Ammerman, 2002. Chemical characteristics and relative bioavailability of supplemental organic zinc sources for poultry and ruminants.J. Anim. Sci. 78: 2039-2054.

Cheng Tingshui and Guo Yuming, 2004.Effects of Salmonella typhymurium Lipopolysaccharide Challenge on the Performance, Immune Responses and Zinc Metabolism of Laying Hens Supplemented with Two Zinc Sources. J. Anim. Sci. 12:
1717-1724.

Huang Y L, Lu L, Luo XG, Liu B. 2009. An optimal dietary zinc level of broiler chicks fed acorn-soybean meal diet. Poultry Science journal, 86, 2582-2589.

Hudson B P, Dozier WA, Wilson JL. 2004. Broiler live performance response to dietary zinc source and the influence of zinc supplementation in broiler breeder diets. Animal feed Science and Technology, 118, 329-335.

Liu, S.B., S. F. Li, L. Lu, J. J. Xie, L. Y. Zhang, R. L. Wang and X. G. Luo, 2013. The effectiveness of zinc proteinate for chicks fed a conventional corn-soybean meal diet. J. Appl. Poult. Res. 22(3), pp.396-403.

Livak KJ, Schmittgen TD. 2001. Analysis of relative gene expression data using realtime quantitative PCR and the $2^{\Delta \Delta} \mathrm{C}(\mathrm{T})$ Method. Methods 25(4): 402-408.

Pimentel, J. L., M. E. Cook, and J. L. Greger. 1991. Research note: Bioavailability of zinc-methionine for chicks. Poult. Sci. 70:1637-1639.

Sunder, G. S., Panda, A. K., Gopinath, N.C.S., Rao, S.V.R., Raju, M., Reddy, M. R. and. Kumar, C.V., 2008. Effects of higher levels of zinc supplementation on performance, mineral availability, and immune competence in broiler chickens. J. Appl. Poult. Res. 17:79-86

Tronina, W., S. Kinal and B. Lubojemska, 2007. Effect of various forms of zinc applied in concentrate mixtures for broiler chickens on its bioavailability as well as meat composition and quality. Pol. J. Food Nutr. Sci. 57(4): 577-581.

Yan, F. and Waldroup, P.W. 2006.Evaluation of MINTREX Manganese as a source of manganese for young broilers. International Journal of Poultry Science. 5:708-703.

\section{How to cite this article:}

Varun, A., N. Karthikeyan, P. Muthusamy, A. Raja and Wilfred Ruban, S. 2017. Real Time PCR Based Expression of Metallothionein and Evaluation of Zn Bioavailability in Chickens Fed Zinc Oxide and Zinc Methionine. Int.J.Curr.Microbiol.App.Sci. 6(7): 845-849. doi: https://doi.org/10.20546/ijcmas.2017.607.103 